\title{
Research on the Development Path of Agricultural Products Circulation in Poverty Counties Based on Tourism Industry Integration
}

\author{
Wang Li \\ Chongqing Business Vocational College \\ Chongqing, 401331 \\ Wangli1981112@126.com
}

\begin{abstract}
By combing and analyzing the urbanization construction process and development trend of the United States and Japan, we explore the endogenous driving force of urbanization construction in poverty-stricken counties in China. This paper takes tourism industry integration as the research foundation, and explores the development mechanism of povertystricken county and the mechanism of agricultural product circulation. After empirical analys is of the basic characteristics of 592 poverty-stricken counties in China, this paper proposes the development path of agricultural products circulation based on tourism industry integration in poverty-stricken counties in China, construct the endogenous driving force of the ecological industry chain to promote different poverty-stricken counties in China to achieve poverty alleviation and promote urbanization based on unique human resources and green resources taking the tourism industry and circulation industry as core industries.
\end{abstract}

Keywords-poverty-stricken counties, tourism industry integration, agricultural product circulation, endogenous power, development path

\section{INTRODUCTION}

Poverty-stricken counties in China have rich human resources and beautiful environmental endowments. Through the integration of tourism industry and the development of agricultural products circulation, it is an important path for poverty-stricken counties to realize characteristic towns, form sustainable development and promote urbanization. How to realize the integration of tourism industry in poverty-stricken counties and promote the balance between production and marketing and supply and demand is not only the inherent requirement of forming characteristic towns and promoting the process of urbanization, but also an important way to realize a well-off society in an all-round way by 2020 .

After nearly 20 years of development, Internet information technology has formed a consumption model of online and offline integration. Businessmen in tourist destinations can tap and attract consumers from all over the world through online platforms, and consumers who experience online shopping can also find all kinds of agricultural products they need through online platforms. Therefore, online, offline and logistics integration of the E-commerce network platform effectively

This paper is one of the key achievements of the 2017 "Focus of the 13th Five-Year Plan” project of Chongqing Education Science, "Research on the Innovative Education Model of Touris m Management under the Guidance of Modern Apprenticeship”, Question No.: 2017-GX-048 reduces the circulation of agricultural products, reduces the cost of agricultural products circulation, and provides a new path, new ways and new ideas for the coordinated development of tourism and circulation industry.

\section{COMPARATIVE STUDY AT HOME AND ABROAD}

By comparing the construction process of small towns with foreign characteristics, we can find the differences between tourism and circulation industry in the process of coordinated development, and explore the regularity of the two, which is conducive to the development of agricultural products circulation in poverty-stricken counties in China based on the integration of tourism industry.

\section{A. Development Experience Abroad}

After more than 200 years of urbanization in the United States, after entering the beginning of this century, there are 35,153 small towns in the United States. Throughout the development of urbanization in the United States, there are three characteristics: one is that the urbanization power is derived from the endogenous role of the self, the second is the gradual and jumping coexistence of urbanization development, and the third is the free circulation of production factors to achieve a balanced distribution of population.

After experiencing the collapse of the economic bubble, Japan has attached importance to the regional urban construction of the local culture characteristics and foundation, forming an efficient ecological and sustainable development road between the animation culture and tourism resources. The construction of small towns in Japan brings four characteristics. The first is to promote the economic agglomeration effect of small towns, the second is to create anime personality and animation brand for small towns, the third is to promote the development of ecological and intensive small towns and the fourth is to improve the quality of residents in small towns and effectively promote urbanization employment.

Looking at the urbanization construction in the United States and Japan, it can be seen that small towns are driven by the government after the growing urban disease, and the construction of small towns has gradually narrowed the gap between urban and rural areas. Subsequently, the government shifted from dominance to the introduction of market capital, 
and the construction of urbanization also shifted from relying on government investment to relying on resource endowment as the core driving force. Finally, tourism and related tourism resources have evolved into the endogenous driving force of urbanization.

\section{B. Domestic Development Characteristics}

Our country's urbanization construction acceptance system has a remarkable impact. Since the reform and opening up, it has been slow to raise funds. In recent years, the scale and quality of urbanization have been improved. Therefore, in the construction of Characteristic Towns in poverty-stricken counties, we should draw on the experience of developed countries to promote the sustainable development of the construction of Characteristic Towns in poverty-stricken counties.

\section{1) The Development Course of Our Country}

From October 1949 to 1978, the number of small towns in China was very small, which was obviously influenced by the macroeconomic policies of politics and economy. During the period 1979-2000, with the gradual clarification of the state's thinking on the construction of small towns and the overall change of the national economy, the number of small towns in our country is increasing rapidly, and it is influenced by the support and adjustment of the state policy to the rural economic development. From 2001 to 2016, influenced by the government's development strategy, the construction of small towns in China has changed from quantity to quality, and many new trends and developments have appeared. Looking at the development of small towns in China, first, it is generally involved in industrial division of labor and cooperation on the southeast coast, later the transfer of industries to the central and western regions has prompted local governments in the central and western regions to pay attention to the construction of small towns. However, the loose industrial system, weak scientific and technological support, low product grade and excessive government dominance are still the important bottlenecks for the development of poverty-stricken counties in China.

\section{2) Research Status in China}

Wang Feng (2014) proposed that the construction of small towns in poverty-stricken counties in the western region should not blindly follow the pattern of the eastern coastal areas, while Lin Li (2014) suggested that the tourism industry should be chosen as the supporting industry, and the regional industrial resources in the construction of small towns in poverty-stricken counties should be driven by tourism. Liu Jing and Zhang Tiwei (2013) believe that the construction of Characteristic Towns in poverty-stricken counties can be divided into three types: scenic spot tourism, border trade economy and resource agglomeration. Yang Huipeng (2017) believes that the integration of the pan-tourism industry should be strengthened online and offline and the small towns in the poverty-stricken areas should be integrated.

Experts and scholars in China have many unique views on the construction of small towns with special features in poverty-stricken counties, but there are still areas worth exploring. First of all, there is a lack of research on the circulation of agricultural products in small towns with poverty-stricken county characteristics. Second, there is a lack of research on the endogenous motivation of small towns with poverty-stricken county characteristics.

\section{3) Path Analysis in China}

There are some trends in the construction of Characteristic Towns in poverty-stricken counties in China, such as the lack of endogenous power in industry, the diversification of green agriculture, the remarkable specialization and the rapid development of service industry. Firstly, from the point of view of endogenous power of industry, the towns with povertystricken county characteristics still focus on the primary industry, and the industrial structure affects the formation of endogenous power. Secondly, from the point of view of green agricultural products, there are problems in the planting and processing of agricultural products in poverty-stricken county towns, such as insufficient deep processing, low circulation efficiency and lack of brand. Based on this, the construction of small towns with poverty-stricken county characteristics should pay attention to environmental protection and green resources endowment, take tourism and other tertiary industries as the core, and construct the endogenous power of the ecological industry chain. At the same time, we should speed up the construction of e-commerce platform integrating on-line, offline and logistics, and ensure the healthy development of small towns with poverty-stricken county characteristics on the basis of green tertiary industry chain.

\section{The Development Momentum of Poverty-stricken COUNTIES BASED ON TOURISM INDUSTRY INTEGRATION AND the Role of Agricultural Product Circulation}

The construction of small towns with poverty-stricken county characteristics should take environmental protection and ecological balance as preconditions, build a harmonious and livable city, develop the tertiary industry with low carbon, realize the dual responsibility of environmental resources endowment and industrial structure transformation, and make the small towns with poverty-stricken county characteristics form the endogenous power with green and low carbon.

\section{A. Development Impetus of poverty-stricken counties Based on Integration of Tourism Industry}

The rapid development of tourism industry has broken the single form of traditional sightseeing and vacation, relying on high-tech and electronic technology and information technology to penetrate into other industries strongly. With the vague margin of tourism industry, new tourism products, new tourism services, new tourism mode has become a new form of tourism industry.

Firstly, the integration of tourism industry promotes the agglomeration of tourist destinations and tourist destinations, and further meets the all-round, individualized, diversified and experiential consumption needs of consumers so that complementary advantages are formed in various industries integrating tourism industry to promote the flow of factor resources endowment to optimize, expand the profit space and business areas, and then form a "attraction-agglomerationconsumption-extension" clustering pattern, enhance the anti- 
risk ability and core competitiveness of tourism industry integration and provide endogenous power for the construction of small towns with poverty-stricken county characteristics. Secondly, the integration of tourism industry can enhance the degree of industrial relevance, effectively enhance the efficiency of inter-industry resource utilization, promote new industries and new formats, and through frequent cooperation, create a symbiotic coupling between industries and create a win-win industrial system to meet the diversified needs, dynamic experience, diversified development, and then innovate tourism products and services, so that consumer agglomeration and tourism agglomeration scale continues to expand, forming a consumer economy chain.

\section{B. The Development of Agricultural Products Circulation Based on the Integration of Tourism Industry}

Tourism industry is showing the trend of diversification, branding and diversification. Especially, the improvement of the circulation efficiency of agricultural products in catering services is an important link in the integration of tourism industry to realize the consumption economic chain, which directly affects the tourism consumption demand and the formation of consumption agglomeration areas and tourism agglomeration areas. Therefore, the quality of catering service consumption is the fundamental guarantee for the standardized and healthy development of tourism industry integration. However, the poverty-stricken counties have not formed a convenient, convenient and unimpeded circulation system of agricultural products, resulting in tourism consumption in industrial integration by the lack of catering service quality.

In general, the integration of tourism industry to promote the economic growth of poverty-stricken counties is still carried out through the various services in the growth of tourism consumption. In terms of its internal causes, it is mainly manifested in the promotion of brand value and service quality, forming the endogenous driving force of economic development in poverty-stricken counties. As far as its external causes are concerned, it is mainly through new technology, new formats and new patterns that the changes in consumer demand are brought about, so as to affect the operation mode of tourism industry integration.

\section{EMPIRICAL ANALYSIS OF THE CiRCULATION OF}

Agricultural Products Based on the INTEgRation of

TOURISM INDUSTRY IN POVERTY-STRICKEN COUNTIES

According to the requirements of the new goal of building a well-off society in an all-round way in the fifth Plenary Session of the 18th CPC Central Committee, under the current standard, China should remove all the 592 impoverished counties in 2020. Detailed statistics are shown in TABLE I.
TABLE I. DIST RIBUTION OF DOMAIN NAMES IN THE LATEST POVERTY COUNTIES IN 2014

\begin{tabular}{|c|c|c|}
\hline $\begin{array}{c}\text { Province and city } \\
\text { name }\end{array}$ & $\begin{array}{c}\text { Number of poverty- } \\
\text { stricken counties }\end{array}$ & Region \\
\hline Hebei Province & 39 & Central Region \\
\hline Shanxi Province & 35 & Central Region \\
\hline Inner Mongolia & 31 & Ethnic Region \\
\hline Jilin Province & 8 & $\begin{array}{l}\text { North-east } \\
\text { Region }\end{array}$ \\
\hline $\begin{array}{l}\text { Heilongjiang } \\
\text { Province }\end{array}$ & 14 & $\begin{array}{l}\text { North-east } \\
\text { Region }\end{array}$ \\
\hline Anhui Province & 19 & Central Region \\
\hline Jiangxi Province & 21 & Central Region \\
\hline Henan Province & 31 & Central Region \\
\hline Hubei Province & 25 & Central Region \\
\hline Hunan Province & 20 & Central Region \\
\hline $\begin{array}{c}\text { Guangxi Zhuang } \\
\text { Autonomous } \\
\text { Region } \\
\end{array}$ & 28 & Ethnic Region \\
\hline Hainan Province & 5 & Coastal Region \\
\hline Chongqing & 14 & Western Region \\
\hline Sichuan Province & 36 & Western Region \\
\hline Guizhou Province & 50 & Western Region \\
\hline Yunnan Province & 73 & Western Region \\
\hline Shaanxi Province & 50 & Western Region \\
\hline Gansu province & 43 & Western Region \\
\hline Qinghai Province & 15 & Western Region \\
\hline $\begin{array}{c}\text { Ningxia Hui } \\
\text { Autonomous } \\
\text { Region } \\
\end{array}$ & 8 & Ethnic Region \\
\hline $\begin{array}{c}\text { Xinjiang Uygur } \\
\text { Autonomous } \\
\text { Region } \\
\end{array}$ & 27 & Ethnic Region \\
\hline
\end{tabular}

According to the latest statistics in 2014, China's povertystricken counties are mainly concentrated in 217 counties in the central region and 375 counties in the western region. According to the statistics of urbanization rate, population, economic growth rate, economic structure and per capita income of poverty-stricken counties, poverty-stricken counties in China have two basic characteristics.

First, the proportion of the primary industry is much higher than that of the secondary and tertiary industries, but affected by the circulation system, the contradiction between supply and demand of agricultural products is very prominent. The production enthusiasm and initiative of farmers in povertystricken counties are not high. At the same time, the circulation of agricultural products in poverty-stricken counties has been in a long and tedious circulation supply chain, so that the cost of circulation increases and the loss of products increases, the degree of preservation decreases, seriously affecting the sale of agricultural products.

Secondly, green tourism resources are very rich, but affected by geographical conditions and infrastructure construction and tourism industry integration is not strong enough. At the same time, the development of tourism 
resources in poverty-stricken counties is difficult to form a strong attraction to tourists and an effective market competitiveness because of the lack of core value mining, resulting the break of the human resources and the tourism industry, which is not only difficult to form the expected return, but also a waste of the beautiful natural environment and tourism resources.

\section{Development Pathof Agricultural Products Circulation IN POVERTy COUNTIES BASED ON TOURISM INDUSTRY INTEGRATION}

\section{A. Establish a Two-way Urban and Rural Circulation Integration System Integrating Online and Offline and Logistics}

First of all, we should use the county as a basic unit to improve the rural information network through market operation. On the one hand, it is necessary to pass the countylevel government, integrate enterprises and private capital, and form a convenience service department and create a non-profit rural information service chain through paid sales of information or shared sharing of resources. On the other hand, the actual market demand of the county should be taken as the expansion of the service function to attract scattered farmers to the farm store e-commerce platform, promote the distribution network layout by buying and selling services and then imitate the city to carry out "unified transceiver address" of county logistics to solve the bottleneck problem of agricultural products circulation. Secondly, we should quickly improve the sales system of fresh agricultural products in poverty-stricken counties through the logistics cold chain system. Through the farm store e-commerce platform, the status of small-lot and multi-batch agricultural products shipments can be effectively gathered, utilize the cold chain transportation equipment of logistics enterprises through deep processing of packaging, enhance the freshness and beauty of agricultural products in poverty-stricken counties taking the speed of express business as an advantage to save logistics costs and prolong storage time.

\section{B. Establish Multi-industry Integration Development with the Primary Industry as the Primary Tertiary Industry}

First of all, poverty-stricken counties should rely on tourism resources to expand green agriculture, enrich the pattern of agricultural development, rely on the special advantages of green agricultural resources, transform from the commercialization and seasonal change of agricultural planting to the experience and enjoyment of green leisure tourism and integrate the agricultural industry and tourism industry and logistics industry into one. Secondly, we should explore farming culture, develop leisure agriculture, experience farming customs and customs, let tourists understand the traditional technology and farming situation participate in labor experience and strengthen tourists' understanding of ecotourism experience and ecological environment. And then through offline experience and online orders, the agricultural products, agricultural products circulation and agricultural products tourism will be mutually guided, which will promote the consumption orders of agricultural products, and open the channels for human resources tourism and special green agriculture.

\section{Establish a Training System to Accelerate the Expansion of Rural E-commerce Talents}

First of all, we should set up the training mechanism of local talents, take the rural talents who love, associate and trust farmers as the main training objects, and set up the training mechanism and training system by means of village-enterprise cooperation and government training. Secondly, it should be promoted to make more rural residents understand e-commerce, establish e-commerce awareness, and participate in ecommerce marketing. Finally, it is necessary to strengthen the participation of higher vocational colleges and secondary vocational colleges, through short-term training during the leisure time, and to use diversified teaching models to enhance the theoretical level and practical experience of rural ecommerce talents.

\section{CONCLUSION}

The small town movement in developed countries such as the United States and Japan has promoted economic development and industrial promotion, while the urbanization movement in poverty-stricken counties in China has a strong administrative color, which is not conducive to industrial layout and driving effect. Therefore, according to the different resources endowment, we should take the information technology as the means to realize the urbanization construction under the market leading. At the same time, from the internal mechanism and external role of tourism industry integration, the formation of consumer agglomeration and tourist agglomeration depends on the improvement of service quality of tourism industry integration. Therefore, the circulation efficiency of agricultural products is the top priority to promote economic growth and urbanization in povertystricken counties.

\section{REFERENCES}

[1] Li Jinjun \& Chen Yunchuan. Analysis on the Format and Problems of the Integration of Modern Tourism Agriculture Industry[J]. Business Economics Research. 2017.8.(15).

[2] Sun Qiong \& Liu Min. The Development of Agricultural Touris m in China and Its Upgrading and Transformation[J].Reformation and Strategy.2017.2.

[3] Li Xiangling. Research on the Evolution Process and Profit Model of Agricultural Tourism Development [J]. Agricultural Economy. 2017.2.

[4] Yang Huipeng. Circulation of agricultural products in small towns in contiguous destitute areas: Dynamic Mechanism and Development Path-From the Perspective of Online and Offline Integration of Pantourism Industry [J]. Research on Finance and Economics. 2017.1:18-31.

[5] Deng Guangshan, Mao Changyi \& Zhang Junyi. Research Status and Prospects of Interactive Effects between Tourism Resources Development and Urbanization Construction [J]. Business Economics Research. 2017.7(13).

[6] Shi Yanran \& Sun Yuling. The Distribution Model of Fresh Agricultural Products Supply Chain[J].China Circulation Economy.2017.1. 